Journal of Telenursing (JOTING)

Volume 2, Nomor 1, Juni 2020

e-ISSN: 2684-8988

p-ISSN: 2684-8996

DOI: https://doi.org/10.31539/joting.v2i1.1093

\title{
ANALISIS INTERVENSI SENAM DIABETES DALAM UPAYA MENURUNKAN KADAR GULA DARAH
}

\author{
Eni Hastuti \\ Akademi Keperawatan Pelni Jakarta \\ hastutieni58@gmail.com
}

\begin{abstract}
ABSTRAK
Penelitian ini bertujuan untuk mengetahui pengaruh senam diabetes terhadap penurunan kadar glukosa darah pada penderita diabetes. Jenis penelitian quasy experiment design rancangan non equivalent control group design sederhana dengan pendekatan studi kasus. Hasil penelitian studi kasus yang telah dilakukan dalam 5 hari selama 30 menit, menunjukkan bahwa senam diabetes efektif menurunkan kadar gula darah pada penderita diabetes mellitus sebesar 7,1\% Simpulan, Senam diabetes yang dilakukan selama 5 hari berturut-turut efektif menurunkan kadar glukosa darah pada penderita diabetes.
\end{abstract}

Kata Kunci : Diabetes Mellitus, Gula Darah, Senam

\section{ABSTRACT}

This study aims to determine the effect of diabetes exercise on reducing blood glucose levels in people with diabetes. This type of research is a quasi-experimental design non-equivalent control group design with a simple case study approach. A case study conducted in 5 days for 30 minutes showed that Diabetes Gymnastics was effective in reducing blood sugar levels in people with Diabetes Mellitus by 7.1\%. In conclusion, diabetes exercises conducted for five consecutive days, effectively lower blood glucose levels in people with diabetes.

Keywords: Diabetes Mellitus, Blood Sugar, Gymnastics

\section{PENDAHULUAN}

Kondisi kesehatan masyarakat di Indonesia semakin kompleks. Prevelensi penyakit menular (PM) memang mengalami penurunan namun untuk penyakit tidak menular (PTM) cenderung mengalami peningkatan dan menjadi tantangan bagi masyarakat pada abad ke-21. PTM sudah bertransisi menjadi beban utama bagi penderitanya dan menyebabkan kematian secara global yaitu $68 \%$ dan di proyeksikan akan terus meningkat pada tahun 2030 (WHO, 2014). Terdapat lima penyakit tidak menular dengan angka kesakitan dan kematian yang tinggi, yaitu penyakit kardiovaskuler, kanker, penyakit pernapasan kronis, Diabetes Melitus (DM), dan cedera (Padila, 2012; Nur \& Warganegara, 2016).

Data Puskesmas Kecamatan Palmerah, total kunjungan rawat jalan di sarana kesehatan puskesmas kecamatan palmerah pada tahun 2016 pada palmerah I sejumlah $3.197(12,4 \%)$, pada Slipi I 3.088 (12,2\%), dan pada slipi II 2.284 
(10,5\%). Data yang didapat dari Puskesmas Kelurahan Slipi II pada bulan September 2016 diketahui jumlah kunjungan sebanyak 931 jiwa, jumlah penderita DM sebanyak 1,07\%, Pada bulan Oktober jumlah kunjungan sebanyak 986 jiwa, jumlah penderita DM sebanyak 4,37\%. Dari data tersebut terjadi peningkatan jumlah penderita diabetes melitus (Profil Puskesmas Kecamatan Palmerah, 2016).

Data survey yang dilakukan mahasiswa Akper Pelni Jakarta yang dimulai pada tanggal 19 Desember 2016 sampai dengan tanggal 27 Desember 2016 dengan jumlah 118 kepala keluarga menunjukan peringkat ke-2, dengan jumlah penderita DM sebanyak 20 jiwa (16,06\%) (Hasil Survey Akper PELNI Jakarta, 2016).

Program pemerintah dalam pengendalian penyakit diabetes mellitus di dalam Depkes, yaitu dengan (1) melakukan pendekatan terhadap faktor risiko penyakit tidak menular terintegrasi di fasilitas pelayanan primer, seperti peningkatan tata laksana faktor risiko utama (konseling berhenti merokok, obesitas, dyslipidemia, hipertensi) di fasilitas pelayanan dasar (puskesmas, dokter keluarga, praktik swasta). (2) posbindu PTM (Pos Pembinaan Terpadu Penyakit Tidak Menular). Merupakan program pengendalian penyakit tidak menular berbasis masyarakat yang bertujuan meningkatkan kewaspadaan masyarakat terhadap faktor risiko, baik terhadap dirinya, keluarga dan masyarakat lingkungan sekitarnya. (3) CERDIK dan PATUH di posbindu PTM dan Balai Gaya Hidup Sehat. Program patuh yaitu P : Periksa kesehatan secara rutin dan ikuti anjuran dokter, A : atasi penyakit dengan pengobatan yang tepat dan teratur, $\mathrm{T}$ : tetap diit sehat dengan gizi seimbang, $\mathrm{U}$ : upayakan beraktifitas fisik dengan aman, $\mathrm{H}$ : hindari rokok, alcohol dan zat karsinogenik lainnya (Kemenkes RI, 2014).

Program CERDIK merupakan pesan singkatan gaya hidup sehat yang disampaikan di lingkungan sekolah, yaitu $\mathrm{C}$ : cek kondisi kesehatan secara berkala, $\mathrm{E}$ : enyahkan asap rokok, $\mathrm{R}$ : rajin aktifitas fisik, $\mathrm{D}$ : diit sehat dengan kalori seimbang, I : istirahat yang cukup, $\mathrm{K}$ : kendalikan stress. Beban penyakit Diabetes Mellitus sangatlah besar apalagi bila terjadi komplikasi. Upaya pengendalian diabetes menjadi tujuan yang sangat pending dalam mengendalikan dampak komplikasi yang menyebabkan beban yang sangat berat baik bagi individu, keluarga maupun pemerintah (Kemenkes RI, 2014).

Upaya penanganan pada pasien diabetes melitus sekaligus juga pencegahan terjadinya komplikasi adalah melakukan upaya pengendalian DM yang salah satu teraturnya pasien DM dalam melakukan aktifitas berolahraga. Dengan berolahraga diharapkan memperbaiki sensitivitas insulin sehingga dapat memperbaiki kadar gula dalam darah. Aktifitas fisik yang juga sering dianjurkan adalah senam diabetes melitus (Salindeho, 2016).

Aktivitas fisik merupakan salah satu pilar penatalaksanaan DM, berdasarkan keterangan tersebut maka dapat dikatakan bahwa salah satu solusi untuk menurunkan kadar gula darah adalah dengan melakukan olahraga seperti senam. Senam adalah menggerakkan badan dengan gerakan tertentu seperti menggeliat, menggerakkan dan meregangkan anggota badan (KBBI, 2019). Salah satu manfaat senam adalah mencegah kegemukan dengan cara membakar kalori tubuh sehingga glukosa darah bisa terpakai untuk energi (Damayanti, 2015). 
Penelitian Sanjaya \& Huda (2016) menunjukkan bahwa senam diabetes dapat menurunkan kadar gula darah yang dilakukan secara rutin 3 kali dalam 1 minggu dengan durasi 15-40 menit. Setelah dilakukan senam diabetes dari 47 sampel selama 1 minggu, didapatkan 37 responden mengalami penurunan kadar gula darah, dan 10 responden mengalami kenaikan kadar gula darah dikarenakan tidak mengontrol pola makan/diet. Penelitian yang dilakukan oleh Rahim (2015) menunjukkan adanya pengaruh gerakan fisik terhadap penuruna kadar gula darah sewaktu.

Dwi (2018) hasil uji statistik chi square menunjukkan senam diabetes efektif terhadap pengendalian kadar gula darah pada penderita Diabetes Melitus dengan ( $p$ $=0.018$ ). Berdasarkan penelitian ini disarankan bagi Puskesmas untuk dapat melakukan upaya pengendalian kadar gula darah pada penderita diabetes melitus dengan teknik non farmakologis salah satunya dengan senam diabetes.

Penelitian Haskas \& Nurbaya (2019) disimpulkan bahwa senam diabetes dapat membantu penderita diabetes melitus dalam mengontrol kadar glukosa dalam darah sehingga kualitas hidup penderita diabetes melitus yang berada di RW 001 \& RW 002 Kelurahan Katimbang Kecamatan Biringkanaya Kota Makassar dapat meningkat dengan terkendalinya glukosa darah penderita.

Berdasarkan penelitian terdahulu yang dilakukan oleh Dahlan et al., (2018) mengenai pengaruh prolanis terhadap pengendalian gula darah terkontrol pada penderita DM di Puskesmas Sudiang kota Makassar di peroleh hasil terdapat korelasi kuat sebesar 0,913 atau 91,3\% pengaruh prolanis dalam pengendalian gula darah terkontrol di Puskesmas Sudiang.

Berdasarkan berbagai data penelitian diatas, perawat sejak awal berperan dalam mengarahkan pemanfaatan terapi latihan fisik bagi penderita diabetes tipe 2 . Peran perawat komunitas juga dapat mengkaji dan meneliti jenis kegiatan jasmani yang aman dan berdampak positif bagi pasien diabetes dalam pengontrolan glukosa meliputi jenis gerakan yang aman intensitas yang optimal dan durasi yang berpengaruh terhadap control glukosa darah penderita diabetes. Aktifitas latihan yang bisa dilakukan adalah aktifitas yang tidak membahanyakan dan bebas dari risiko cidera.

\section{METODE PENELITIAN}

Jenis penelitian quasy experiment design dengan rancangan non equivalent control group design, dengan 1 kelompok intervensi dan 1 kelompok kontrol. Tehnik pengambilan sampel purposive sampling. Jumlah total responden sebanyak 2 orang dengan mengambil sampel 2 subjek penelitian, instrumen yang digunakan yaitu lembar wawancara, lembar observasi, lembar observasi balance exercise. Kriteria inklusi pada sampel penelitian ini adalah lansia yang lama menderita diabetes diatas 3 tahun ,berusia 65-80 tahun,belum pernah melakukan senam diabetes,tinggal di RW 01 Kel. Slipi Kec. Palmerah, bersedia menjadi subyek penelitian. 


\section{HASIL PENELITIAN}

Tabel. 1

Penelitian Subjek 1

\begin{tabular}{ccccc}
\hline No & Pertemuan & Sebelum Tindakan & Sesudah Tindakan & Keterangan \\
\hline 1. & Pertama & GDS pre senam 308mg/dl. & Post senam $298 \mathrm{mg} / \mathrm{dl}$ & Turun $10 \mathrm{mg}$ \\
2. & Dua & GDS Pre senam 301mg/dl & Post senam $291 \mathrm{mg} / \mathrm{dl}$ & Turun $10 \mathrm{mg}$ \\
3. & Tiga & GDS pre senam $289 \mathrm{mg} / \mathrm{dl}$ & post senam $279 \mathrm{mg} / \mathrm{d}$ & Turun $10 \mathrm{mg}$ \\
4. & Empat & GDS pre senam $288 \mathrm{mg} / \mathrm{dl}$ & post senam $273 \mathrm{mg} / \mathrm{dl}$ & Turun $10 \mathrm{mg}$ \\
5. Lima & GDS pre senam 303mg/dl & post senam & Turun $10 \mathrm{mg}$ \\
& & $283 \mathrm{mg} / \mathrm{dl}$ & \\
\hline
\end{tabular}

Berdasarkan tabel 1 dimana tindakan intervensi senam DM yang dilakukan kepada pasien pada pertemuan ke 1 sampai pertemuan ke 5 sebelum dilakukan intervensi senam DM gds pasien di ukur masih tinggi dengan kisaran 208$308 \mathrm{mg} / \mathrm{dl}$ sesudah dilakukan tindakan post senam DM mengalami penurunan yang sangat baik diamana hari ke 1 sampai hari ke 5 mengalami penurunan dengan kisaran 10mg. Senam DM ini sangat berguna bagi kesehatan pasien.

Tabel. 2

Penelitian Subjek 2

\begin{tabular}{|c|c|c|c|}
\hline No Pertemuan & Sebelum Tindakan & Sesudah Tindakan & Keterangan \\
\hline Pertama & GDS pre senam $305 \mathrm{mg} / \mathrm{dl}$. & post senam $310 \mathrm{mg} / \mathrm{dl}$. & Naik $5 \mathrm{mg}$ \\
\hline Dua & GDS Pre senam $300 \mathrm{mg} / \mathrm{dl}$ & Post senam $310 \mathrm{mg} / \mathrm{dl}$ & Naik $5 \mathrm{mg}$ \\
\hline Tiga & GDS pre senam $320 \mathrm{mg} / \mathrm{dl}$ & post senam $310 \mathrm{mg} / \mathrm{dl}$ & Turun $10 \mathrm{mg}$ \\
\hline 4. Empat & GDS pre senam $299 \mathrm{mg} / \mathrm{dl}$ & post senam $289 \mathrm{mg} / \mathrm{dl}$ & Turun $10 \mathrm{mg}$ \\
\hline 5. Lima & GDS pre senam $297 \mathrm{mg} / \mathrm{dl}$ & post senam $287 \mathrm{mg} / \mathrm{dl}$ & Turun $10 \mathrm{mg}$ \\
\hline
\end{tabular}

Berdasarkan tabel 2 dimana tindakan intervensi senam DM yang telah dilakukan responden kepada pasien pada pertemuan ke 1 dan ke 2 sebelum dilakukan tindakan senam DM gds pasien di ukur mengalami peningkatan dengan kisaran 300-305mg/dl, sesudah dilakukan tindakan senam dm gds pasien masih mengalami peningkatan. Intervensi selanjutya yang dilakukan pada pertemuan ke 3 sampai ke 5 sebelum tindakan senam gds pasien masi tinggi kisaran $297-320 \mathrm{mg} / \mathrm{dl}$ dan sesudah dilakukan tindakan intervensi senam gds pasien mengalami penuruanan yang sangat signifikan. terapi senam ini salah satu terapi yang bisa membantu menurunkan kadar gulah darah dalam tubuh pasien.

\section{PEMBAHASAN}

Pembahasan ini membahas tentang hasil penelitian yang dilakukan selama 10 hari. Pada subyek penelitian I, ditemukan dampak lingkungan yang berdampak pada peningkatan kadar gula darah, yaitu adanya hambatan yang terdapat pada lingkungan berupa Berdasarkan pengamatan, kondisi lingkungan subyek penelitian I tampak padat penduduk, kumuh, kotor, kurang ventilasi, serta kurang pencahayaan matahari. Rumah masuk ke dalam gang yang jarang dilewati orang lain. Saat dikunjungi dirumahnya sedang ramai oleh cucu-cucunya yang sedang bermain, terkadang bertengkar dan menangis yang membuat pusing, suka makan cemilan dilihat dari banyaknya cemilan yang ada di dalam rumah, mulai dari makanan ringan dan buah-buahan, dikarenakan didalam rumah banyak anak kecil 
yang tinggal. kondisi rumah tampak kotor dan berantakan, ruang tamu, ruang makan dan ruang tidur ada dalam satu ruangan.

Berdasarkan pengamatan, kondisi lingkungan rumah Subyek Penelitian II bersih namun padat penduduk, pencahayaan dan ventilasi cukup. Lingkungan rumah jauh dari kebisingan. Menantunya setiap hari datang berkunjung kerumah, karena rumah subyek penelitian II sepi.

Karakteristik subyek penelitian pada penelitian ini, terdapat perbedaan pada karakteristik kedua subyek penelitian. Pada Subyek Penelitian I, berjenis kelamin perempuan berusia 68 tahun lama menderita DM sudah 14 tahun, disebabkan karena obesitas, sebagai ibu rumah tangga yang tinggal bersama anak dan cucunya. Aktivitas yang biasa dilakukan dirumah mencuci piring, merapikan rumah, menjemur dan mengangkat pakaian, terkadang jalan santai dan berbincang di teras tetangga. Sedangkan pada Subyek II, berjenis kelamin laki-laki berusia 78 tahun, tidak bekerja, tinggal bersama istri, anak dan menantunya, aktivitas yang biasa dilakukan hanya duduk, tidur dan menonton tv. Kedua subyek penelitian samasama tidak teratur pada pola makan dan minum obat.

Pada subyek penelitian I, biasa melakukan pekerjaan rumah seperti menjemur, mencuci, merapikan rumah. Sedangkan pada subyek penelitian II, hanya tidur dan menonton tv. Kedua subyek penelitian juga tidak bekerja. Pada subyek penelitian I, kadar gula darah selalu mengalami penurunan pada pemeriksaan post senam diabetes. Sedangkan pada subyek penelitian II, mengalami peningkatan kadar gula darah pada post senam diabetes.

Pada penelitian ini, kedua subyek penelitian ini, memiliki pola makan yang tidak teratur, masih tergantung dengan apa yang mereka inginkan. Pada Subyek Penelitian I, masih suka minum kopi saset yang mengandung gula tinggi, gorengan seperti pisang dan ganasturi dan waktu makan yang tidak teratur. Pada subyek penelitian II, suka cemilan manis dan tidak teraturnya waktu makan.

Intervensi senam diabetes, setelah dilakukan intervensi senam diabetes selama 5 hari berturut-turut pada kedua subyek penelitian selama 30 menit. Terjadi perbedaan penurunan kadar gula darah yang berbeda pada kedua subyek penelitian.

Pada subyek penelitian I, selama latihan senam mampu mengikuti gerakan senam yang di ajarkan dan mampu mengingat 3 gerakan senam. Saat pertamakali diajarkan senam, masih tampak kaku dalam pergerakannya. Dari tingkat kemandirian, subyek penelitian I belum mampu melakukan senam diabetes secara mandiri, karena tidak ingat urutan senam dan mudah lupa, maka dari itu setiap kali senam harus tetap di latih ulang. Hasil dari intervensi pada Subyek Penelitian I, selama 5 hari mengalami penurunan kadar gula darah sebanyak $25 \mathrm{mg} / \mathrm{dl}$, dengan nilai awal GDS 308mg/dl, dan nilai akhir GDS 283mg/dl. Selama 4 hari implementasi, penurunan gula darah sebanyak $10 \mathrm{mg} / \mathrm{dl}$. Sedangkan pada hari ke-5 terjadi penurunan nilai gula darah sebanyak $20 \mathrm{mg} / \mathrm{dl}$.

Penelitian Haskas \& Nurbaya (2019) disimpulkan bahwa senam diabetes dapat membantu penderita diabetes melitus dalam mengontrol kadar glukosa dalam darah sehingga kualitas hidup penderita diabetes melitus yang berada di RW $001 \&$ RW 002 Kelurahan Katimbang Kecamatan Biringkanaya Kota Makassar dapat meningkat dengan terkendalinya glukosa darah penderita.

Sedangkan, pada subyek penelitian II, selama latihan senam mampu mengikuti gerakan senam yang di ajarkan dan masih tampak kaku dalam pergerakannya, namun setiap kali latihan harus selalu diajarkan dan diarahkan karena selalu lupa gerakan yang diajarkan. Hasil dari intervensi pada Subyek Penelitian II, selama 5 hari melakukan senam diabetes, mengalami penurunan kadar 
gula darah sebanyak $18 \mathrm{mg} / \mathrm{dl}$, dengan nilai awal GDS 305mg/dl, dan nilai akhir GDS $287 \mathrm{mg} / \mathrm{dl}$. Pada hari pertama dan kedua, terjadi peningkatan kadar gula darah setelah senam, pada hari ke-1 mengalami kenaikan $5 \mathrm{mg} / \mathrm{dl}$, dan pada hari ke-2 mengalami kenaikan $10 \mathrm{mg} / \mathrm{dl}$. Kemudian turun perlahan pada hari ke-3 sampai dengan hari ke-5, masing-masing mengalami penurunan $10 \mathrm{mg} / \mathrm{dl}$. Hal ini tidak terlepas dari faktor yang mempengauhi seperti aktivitas, kepatuhan minum obat dan pola makna teratur.

Perbandingan hasil intervensi yang dilaksanakan setelah 5 hari melakukan senam diabetes, maka hasil dari subyek penelitian I, kadar gula darah mengalami penurunan, nilai gula darah sebelumnya $308 \mathrm{mg} / \mathrm{dl}$, setelah 5 hari melakukan senam diabetes, mengalami penurunan sebanyak $25 \mathrm{mg} / \mathrm{dl}$ menjadi $283 \mathrm{mg} / \mathrm{dl}$. Pada subyek penelitian II, juga mengalami penurunan kadar gula darah sebanyak $18 \mathrm{mg} / \mathrm{dl}$, dari $305 \mathrm{mg} / \mathrm{dl}$ menjadi $287 \mathrm{mg} / \mathrm{dl}$. Keluhan yang sering dirasakan selanjutnya yaitu kedua subyek merasakan sering lapar. Setelah dilakukan senam diabetes selam 5 hari, hasil penelitian pada subyek penelitian I dan subyek penelitian II, mengatakan masih sering terasa lapar.

Penelitian ini juga sejalan dengan penelitian yang dilakukan Puspihapsari (2019) hasil dari penelitian ini yaitu ada perubahan kadar gula darah sewaktu pada responden yang signifikan, dengan nilai $\mathrm{p}$ value $(\mathrm{p}=0,001)$. Kesimpulannya pemberian senam diabetes mellitus yang dilakukan secara rutin 1x dalam 1 minggu dapat menurunkan kadar gula darah sewaktu di Puskesmas Purwodiningratan Kecamatan Jebres Kota Surakarta.

Penelitian yang dilakukan Rehmaita et al., (2017) hasil penelitian menunjukkan adanya pengaruh yang signifikan terhadap penurungan kadar gula darah (KGD) pada pasien diabetes mellitus type II akibat kegiatan senam diabetes $(\mathrm{p}$-value $=0.002)$ dan jalan kaki $(\mathrm{p}$ value $=0.001)$. Kegiatan olahraga yang baik, benar, teratur dan terukur dapat dipertimbangkan untuk menstabilkan kadar gula darah (KGD) pasien diabetes mellitus type II.

Penelitian Novita et al., (2018) ada perbedaan rerata kadar gula darah pre dan post pada kelompok intervensi $(\mathrm{p}=0,014)$, namun cenderung mengalami peningkatan. Penelitian yang dilakukan oleh Utomo et al., (2016) juga menghasilkan hal yang sama yaitu terdapat perbedaan penurunan kadar gula darah sewaktu antara kelompok terpapar dan kelompok tidak terpapar (nilai p=0,0001). Penurunan ratarata gula darah sewaktu pada kelompok terpapar 2,3 kali lebih besar daripada kelompok tidak terpapar $(31,5 \mathrm{mg} / \mathrm{dl}$ berbanding $13,5 \mathrm{mg} / \mathrm{dl})$. Jadi, senam efektif dalam menurunkan kadar gula darah.

Penelitian yang dilakukan Sari et al., (2018) di Dusun Candimulyo Kecamatan Jombang hasil penelitian menunjukkan bahwa GDA sebelum senam sebagian besar sedang yaitu 5 responden (50\%), setelah intervensi sebagian besar rendah yaitu $6(60 \%)$ responden. Hasil uji wilcoxon test didapatkan nilai p 0,008, dapat disimpulkan ada pengaruh senam diabetes terhadap kadar gula darah pada penderita diabetes mellitus tipe 2 . Adanya pengaruh kadar glukosa dengan aktifitas olah raga sangat erat kaitannya dengan sistem pembakaran glukosa darah dalam sel melalui kinerja insulin. Sensitifitas insulin sangat erat kaitannya dengan aktifitas olahraga, orang yang melakukan olahraga akan mempunyai kadar glukosa yang seimbang dikarenakan efektifnya insulin dalam merubah glukosa menjadi energi.

Latihan sangat penting dalam penatalaksanaan diabetes karena efeknya dapat menurunkan kadar glukosa darah dan mengurangi resiko kardiovaskuler. Latihan akan menurunkan kadar glukosa darah dengan meningkatkan pengambilan glukosa oleh otot dan memperbaiki pemakaian insulin. Sirkulasi darah dan tonus otot juga 
diperbaiki dengan berolahraga. Penderita diabetes harus diajarkan untuk selalu melakukan latihan pada saat yang sama (sebaiknya ketika kadar glukosa darah mencapai puncaknya) dan intensitas yang sama setiap harinya. Latihan yang dilakukan setiap hari secara teratur lebih dianjurkan daripada latihan sporadik (Lindawati, 2019).

Penelitian Lindawati (2019) menyatakan bahwa ada perbedaan yang signifikan rata-rata gula darah sewaktu antara sebelum dan setelah intervensi. Manfaat olahraga pada diabetisi antara lain meningkatkan penurunan kadar glukosa darah, mencegah kegemukan, ikut berperan dalam mengatasi kemungkinan terjadinya komplikasi aterogenik, gangguan lipid darah, peningkatan tekanan darah, hiperkoagulasi darah. Keadaan-keadaan ini mengurangi risiko penyakit jantung coroner (PJK) dan meningkatkan kualitas hidup diabetes dengan meningkatnya kemampuan kerja dan juga memberikan keuntungan secara psikologis.

Manfaat olahraga pada diabetisi antara lain meningkatkan penurunan kadar glukosa darah, mencegah kegemukan, ikut berperan dalam mengatasi kemungkinan terjadinya komplikasi aterogenik, gangguan lipid darah, peningkatan tekanan darah, hiperkoagulasi darah. Keadaan-keadaan ini mengurangi risiko penyakit jantung coroner (PJK) dan meningkatkan kualitas hidup diabetes dengan meningkatnya kemampuan kerja dan juga memberikan keuntungan secara psikologis (Lindawati, 2019).

Senam diabetes dilakukan untuk menurunkan dan mengontrol kadar gula darah pada penderita diabetes mellitus, setelah diberikan intervensi senam diabetes didapatkan hampir seluruhnya penderita diabetes mengalami penurunan kadar gula darah, hal ini dikarenakan pada saat melakukan senam terjadi peningkatan pemakaian glukosa oleh otot, senam juga untuk membakar kalori tubuh sehingga glukosa darah bisa terpakai untuk energi. Dalam mengontrol dan menurunkan kadar gula darah dipengaruhi oleh beberapa faktor lainya juga seperti berat badan, pendidikan dan faktor umur, dengan mengontrol pola makan/diet, meningkatkan pengetahuan tentang kesehatan, memberikan latihan fisik yaitu dengan senam diabetes yang dapat mengontrol dan menurunkan kadar gula darah sebagai modal pengobatan kedua (Sanjaya \& Huda, 2016).

Melakukan olahraga yang baik dan teratur membuat peningkatan aliran ke otot dengan cara pembukaan kapiler (pembuluh darah kecil di otot) dan hal tersebut akan menurunkan tekanan pada otot yang pada gilirannya akan meningkatkan penyediaan dalam jaringan otot itu sendiri. Senam diabetes merupakan jenis senam aerobic low impact yang ditekankan pada gerakan ritmik otot, sendi, vaskuler dan saraf dalam benruk peregangan dan relaksasi. Upaya berikut sangat tepat dalam menangani pasien diabetes melitus sekaligus juga mencegah terjadinya komplikasi dengan mengendalikan diabetes melitus penderita (Salindeho et al., 2016).

Berdasarkan kegiatan ini penderita menyadari pentingnya melakukan aktivitas fisik diantaranya senam/olahraga dikarenakan dalam mengendalikan glukosa darah tidak akan efektif jika hanya dengan mengandalkan pengobatan (Ruben et al., 2016).

Penelitian Gusti \& Septi (2015) diabetes disebut the silent killer karena hampir sepertiga orang dengan diabetes tidak mengetahui mereka menderita diabetes mellitus, sampai penyakit tersebut berkembang menjadi serius yang berdampak pada organ atau sistem tubuh lainnya dan mengakibatkan komplikasi. Tujuan penelitian ini yaitu untuk mengetahui pengaruh senam kaki diabetes terhadap penurunan kadar gula darah pada pasien diabetes mellitus tipe 2. Desain penelitian ini menggunakan one-group pre-post-test design, dengan purposive 
sampling. Sampel yang diambil sebanyak 20 responden. Penelitian dilaksanakan di Puskesmas Balongpanggang bulan Desember 2014. Variabel independennya adalah senam kaki diabetes, dan variabel dependennya adalah penurunan kadar gula darah. Data penelitian ini diambil dengan menggunakan observasi. Hasil uji statistik Wilcoxon Signed Rank Test didapatkan hasil hari-1 ( $\alpha$ hitung) $=0,000$ dan korelasi $\mathrm{Z}=3,202$, hari-2 $(\alpha$ hitung $)=0,000$ dan korelasi $\mathrm{Z}=3,352$, hari-3 ( $\alpha$ hitung) $=$ 0,000 dan korelasi $Z=4,128$ artinya ada pengaruh kuat senam kaki diabetes terhadap penurunan kadar gula darah pada pasien diabetes mellitus tipe 2. Senam kaki diabetes sangat dibutuhkan dalam pengelolaan diabetes mellitus, latihan jasmani secara teratur dapat menurunkan kadar gula darah.

Keluhan yang dirasakan berikutnya yaitu kedua subyek mengeluh sering terbangun saat malam hari untuk buang air kecil. Setelah dilakukan senam diabetes selam 5 hari, hasil penelitian pada subyek penelitian I mengatakan sekarang tidur menjadi terasa nyenyak. Pada subyek penelitian II, mengatakan tidur terasa lebih nyenyak setelah latihan senam diabetes. Keluhan terakhir yang dirasakan yaitu kedua subyek mengeluh merasa haus terus. Setelah dilakukan senam diabetes selam 5 hari, hasil penelitian pada subyek penelitian I mengatakan masih merasa haus.

Penelitian Achmad et al., (2016) diabetes mellitus type 2, merupakan salah satu keluhan umum yang sering dialami oleh pasien berumur diatas 45 tahun. Indonesia sendiri merupakan negara ke 4 paling banyak terkena kasus diabetes mellitus. Hal tersebut dapat terjadi karena pola makan yang tidak terjaga, olahraga yang kurang, dan lifestyle yang tidak sesuai. Senam diabetes merupakan langkah awal dalam mengatasi diabetes hasil analisis dengan korelasi wilcoxon menunjukkan bahwa terdapat hubungan yang signifikan antara senam diabetes terhadap kadar gula darah puasa dan 2 jam post prandial $(\mathrm{p}=0,000)$ yang berarti senam merupakan salah satu faktor yang dapat menurunkan kadar gula darah puasa dan 2 jam post prandial. Kesimpulan: terdapat hubungan yang signifikan antara senam diabetes terhadap kadar gula darah puasa dan 2 jam post prandial.

\section{SIMPULAN}

Faktor stress merupakan salah satu faktor yang menyebabkan meningkatnya gula darah. Karakteristik penderita diabetes mellitus yaitu usia, lama menderita, pola makan, aktivitas, obesitas dan riwayat penyakit. Kondisi yang sering dirasakan oleh penderita diabetes yaitu sering merasa haus (polidipsi), sering merasa lapar (polifagi), dan sering pipis (poliuri). Senam diabetes yang dilakukan selama 5 hari berturut-turut efektif menurunkan kadar glukosa darah pada penderita diabetes.

\section{SARAN}

\section{Bagi Pelayanan Keperawatan}

Perawat dapat berperan aktif dalam mengembangkan dan memilih jenis aktifitas latihan yang aman bagi penderita diabetes mellitus.

\section{Bagi Institusi Pendidikan Keperawatan}

Mengembangkan aktifitas senam diabetes dalam berbagai kegiatan untuk menghasilkan berbagai jenis aktifitas yang menyenangkan dan tepat bagi penderita diabetes. 


\section{Bagi Peneliti}

Sebelum melakukan penelitian, diharapkan lebih banyak mendapatkan referensi tentang intervensi dan penyakit yang akan diteliti, agar lebih mengetahui banyak hal.

\section{DAFTAR PUSTAKA}

Achmad, H., Irma S., \& Dwi, N. P. (2016). Hubungan Senam Diabetes terhadap Kadar Gula Darah Puasa dan 2 Jam Post Prandial Pasien Dm Type 2 Www.Researchgate.Net/Publication/326350684

Akademi Keperawatan Pelni Jakarta. (2016). Survey Kesehatan Masyarakat di RW 05 Kelurahan Slipi. Jakarta

Damayanti, S. (2015). Hubungan Frekuensi Senam Diabetes Mellitus DenganKadar Gula Darah Kadar Kolestrol, dan Tekanan Darah pada Penderita Diabetes Mellitus Tipe 2 di Rs Persadia Yogyakarta. J Med Respati:p, 76-88

Dahlan, N., Bustan, M. N., \& Kurnaesih, E. (2018). Pengaruh Prolanis terhadap Pengendalian Gula Darah Terkontrol pada Penderita DM di Puskesmas Sudiang Kota Makassar. In Prosiding Seminar Nasional Sinergitas Multidisiplin Ilmu Pengetahuan dan Teknologi, 1, 3949

Dwi, C, R. (2018). Efektifitas Pemberian Latihan Fisik : Senam Diabetes terhadap Pengendalian Kadar Gula Darah pada Penderita Diabetes Melitus. Jurnal Ilmu Kesehatan (JIK), 2(2)

Haskas, Y., \& Nurbaya, S. (2019). Upaya Peningkatan Kulitas Hidup Penderita DM dengan Memberikan Pelatihan Senam Diabetes. Indonesian Journal of Community Dedication (IJCD), 1(1), 14-18

Gusti, R. R, Septi, F. (2015). Senam Kaki Diabetes Menurunkan Kadar Gula Darah Pasien Diabetes Mellitus Tipe. Journal of Ners Community 6(2), 189 - 19

Kemenkes (2014). Info Datin situasi dan Analisis Diabetes Mellitus. Jakarta : Pusat Data dan Informasi Kementrian Kesehatan RI

Lindawati, W. (2019). Pengaruh Senam Diabetes terhadap Kadar Gula Darah pada Pasien Diabetes Mellitus Tipe 2 di Wilayah Kerja Puskesmas Periuk Jaya Kota Tangerang. Medikes (Media Informasi Kesehatan), 6(2), 247-254

Nur, N. N., \& Warganegara, E. (2016). Faktor Risiko Perilaku Penyakit Tidak Menular. Majority, 5(2), 88-94

Padila, P. (2012). Buku Ajar Keperawatan Medikal Bedah. Yogyakarta: Nuha Medika

Puspihapsai, L. D., \& Widodo, A. (2019). Pengaruh Senam Diabetes Mellitus terhadap Penurunan Kadar Gula Darah Sewaktu (GDS) Peserta Prolanis di Puskesmas Purwodiningratan. Universitas Muhammadiyah Surakarta

Novita, A. R., Kartini, A., \& Pradigdo, S. F. (2018). Pengaruh Frekuensi Senam Diabetes Mellitus terhadap Kadar Gula Darah (Studi pada Kelompok Umur $\geq$ 45 Tahun di Kota Semarang). Jurnal Kesehatan Masyarakat (e-Journal), 6(4), 168-175

Rehmaita, R., Mudatsir, M., \& Tahlil, T. (2017). Pengaruh Senam Diabetes dan Jalan Kaki terhadap Penurunan Kadar Gula Darah pada Pasien DM Tipe 2 di Puskesmas Krueng Barona Jaya Aceh Besar. Jurnal Ilmu Keperawatan, 5(2), 84-89

Ruben, G., Rottie, J., \& Karundeng, M. Y. (2016). Pengaruh Senam Kaki Diabetes terhadap Perubahan Kadar Gula Darah pada Pasien Diabetes Mellitus Tipe 2. Ejournal Keperawatan 
Salindeho, A., Mulyadi, M., \& Rottie, J. (2016). Pengaruh Senam Diabetes Mellitus terhadap Kadar Gula Darah Penderita Diabetes Mellitus Tipe 2 di Sanggar Senam Persadia Kabupaten Gorontalo. Keperawatan (e-Kp), 4(1), 1-7

Sanjaya, A. F., \& Huda, M. (2016). Pengaruh Senam Diabetes terhadap Penurunan Kadar Gula Darah pada Penderita Diabetes Mellitus di Wilayah Kerja Puskesmas Peterongan Jombang. journal.stikespemkabjombang.ac.id

Sari, D. M., Rosyidah, I., \& Fatoni, I. (2018). Pengaruh Senam Diabetes Mellitus terhadap Kadar Gula Darah pada Penderita Diabetes Mellitus Tipe 2 di Dusun Candimulyo Desa Candimulyo Kabupaten Jombang. Skripsi. STIKES Insan Cendekia Medika Jombang

Utomo, O. M., Azam, M., \& Ningrum, D. N. A. (2016). Pengaruh Senam terhadap Kadar Gula Darah Penderita Diabetes. Unnes Journal of Public Health, 1(1)

WHO. (2014). Global Report on Diabetes. Switzerland: World Health Organization 